\title{
Evaluation of best management practices to reduce nutrient contaminant losses in runoff from broiler litter-amended soils. I. Alum additions ${ }^{1,2}$
}

\author{
Gustavo A. Martínez-Rodríguez ${ }^{3 *}$, Raúl Macchiavellit \\ and Miguel A. Vázquez $z^{5}$
}

J. Agric. Univ. P.R. 94(1-2):41-59 (2010)

\begin{abstract}
The effect of alum $\left[\mathrm{Al}_{2}\left(\mathrm{SO}_{4}\right)_{3} \cdot 14 \mathrm{H}_{2} \mathrm{O}\right]$ on reducing phosphorus $(\mathrm{P})$ concentrations in runoff water from broiler litter-amended soils was evaluated in various simulated rainfall events. Additions of alum at a $20 \%(\mathrm{w} / \mathrm{w})$ rate caused a significant reduction in the "soluble" $\left(\mathrm{CaCl}_{2}\right.$-extractable) $\mathrm{P}$ fraction of the broiler litter matrix. As a result, the soluble $P$ fraction added to the soils through litter application was $43 \%$ and $75 \%$ less for the $6 \mathrm{t} / \mathrm{ha}$ and the $20 \mathrm{t} / \mathrm{h}$ a litter treatments with alum than for their untreated $(0$ alum) counterparts. Total phosphorus (TP) concentrations in runoff for the $6 \mathrm{t} / \mathrm{ha}$ and $20 \mathrm{t} / \mathrm{ha}$ treatments with no alum were highly enriched, averaging $2.59 \mathrm{mg} / \mathrm{L}$ and $6.10 \mathrm{mg} / \mathrm{L}$, respectively. At the highest litter rate (i.e., $20 \mathrm{t} / \mathrm{ha}$ ) the $20 \%$ alum treatment achieved a $52 \%$ reduction in the concentration of TP in runoff as compared to that of the no-alum treatment. However, the impact of alum was more notable in reducing dissolved $P$ (DP) losses. Average DP concentration losses for the $\mathbf{2 0} \mathrm{t} / \mathrm{ha}$ broiler litter rate (no alum) was $3.55 \mathrm{mg} / \mathrm{L}$, a value significantly higher than the $1.0 \mathrm{mg} / \mathrm{L}$ threshold that has been suggested as a potential limit to control runoff $P$ losses from agricultural fields. At said broiler litter application rate the $10 \%$ and $20 \%$ alum treatments resulted in reductions of $58 \%$ and $70 \%$ of the DP concentrations in runoff, respectively. The observed DP concentration losses from the litter treatments containing $20 \%$ alum met the 1 $\mathrm{mg} / \mathrm{L}$ threshold value in practically all instances. Total $\mathrm{P}$ losses in runoff were positively correlated with both the amount of $\mathrm{CaCl}_{2}$-extractable $\mathrm{P}$ applied to the soils and soil P levels (Olsen) during different stages of the simulation events. The nutritional contents ( $N, P$, and $K)$ of the Bermuda grass samples were reflective of the broiler litter rate. Higher nutritional contents were generally observed with the 20 t/ha treatments as com-
\end{abstract}

${ }^{1}$ Manuscript submitted to the Editorial Board 28 October 2009.

${ }^{2}$ We appreciate the collaboration of José L. Guzmán, Onilda Santana, Vidal Santiago, and Francisco Castro on this project.

${ }^{3}$ Professor, Crops and Agroenvironmental Sciences Department, College of Agricultural Sciences, University of Puerto Rico-Mayagüez Campus. *For correspondence: Email: tavomarti@hotmail.com.

${ }^{4}$ Professor, Crops and Agroenvironmental Sciences Department, College of Agricultural Sciences, University of Puerto Rico-Mayagüez Campus.

${ }^{5}$ Research Associate, Crops and Agroenvironmental Sciences Department, Agricultural Experiment Station at Río Piedras, Puerto Rico. 
pared to those at the 6 tha rate with no alum, even though the effects were statistically significant only for nitrogen. Alum did not seem to exert a significant impact on nutritional content of the Bermuda grass, although a slight decrease (non significant) in both $\mathrm{N}$ and $\mathrm{P}$ was observed at the $20 \%$ alum rate for the $20 \mathrm{t} / \mathrm{ha}$ broiler litter rate.

Key words: simulated rainfall, runoff, alum, water quality, nutrients, tropical soils

\section{RESUMEN}

Evaluación de mejores prácticas de manejo para reducir las pérdidas de nutrientes contaminantes en escorrentía desde suelos enmendados con camada de pollos parrilleros. I. Adiciones de alum

El efecto de alum $\left[\mathrm{Al}_{2}\left(\mathrm{SO}_{4}\right)_{3} \cdot 14 \mathrm{H}_{2} \mathrm{O}\right]$ en la reducción de las concentraciones de fósforo (P) en las aguas de escorrentía desde los suelos enmendados con residuos de camadas de pollos parrilleros se evaluó en varios eventos de lluvia simulada. Adiciones de alum a razón de $20 \%$ (peso/peso) causaron una reducción significativa en la fracción de $\mathbf{P}$ "soluble" ( $\mathrm{CaCl}_{2}$-extraíble) presente en la matriz de la camada de pollos parrilleros. Como resultado, el $\mathrm{P}$ soluble añadido al suelo se redujo en un $43 \%$ y un $75 \%$ para los tratamientos de 6 t/ha y 20 t/ha de residuos de camada de pollos parrilleros con alum en comparación con sus contrapartes sin alum. Las concentraciones de $\mathbf{P}$ total en la escorrentía de los tratamientos $6 \mathrm{t} / \mathrm{ha}$ y 20 t/ha de residuos de camada de pollos parrilleros sin alum resultaron altamente enriquecidas, promediando 2.59 y $6.10 \mathrm{mg} / \mathrm{L}$, respectivamente. En la dosis más alta de residuos de camada de pollos parrilleros ( $20 \mathrm{t} / \mathrm{ha}$ ), el tratamiento de $20 \%$ de alum logró una reducción de $52 \%$ en la concentración de $P$ total en la escorrentía relativo al tratamiento sin alum. Sin embargo, el efecto más notable de alum fue en la reducción de las pérdidas de $P$ disuelto. Las pérdidas en las concentraciones de $P$ disuelto promedio en el tratamiento de 20 t/ha de residuos de camada de pollos parrilleros (sin alum) fue de $3.55 \mathrm{mg} / \mathrm{L}$, un valor significativamente mayor que el umbral de $1.0 \mathrm{mg} / \mathrm{L}$ que ha sido sugerido como el límite potencial para el control de pérdidas de $\mathrm{P}$ por escorrentía de predios agrícolas. En dicha dosis de aplicación los tratamientos de $10 \%$ y $20 \%$ de alum alcanzaron reducciones de $58 \%$ y $70 \%$ en las concentraciones de $\mathbf{P}$ disuelto en la escorrentía, respectivamente. Las pérdidas en las concentraciones de $\mathrm{P}$ disuelto observadas para los tratamientos con $20 \%$ de alum cumplieron con el valor umbral de $1.0 \mathrm{mg} / \mathrm{L}$ en prácticamente todos los casos, irrespectivamente de la dosis de residuos de camada de pollos parrilleros evaluada. Las pérdidas de $P$ total en la escorrentía fue correlacionada positivamente tanto con la fracción de $\mathrm{P}$ soluble (extraíble con $\mathrm{CaCl}_{2}$ ) aplicado a los suelos, como con los niveles de $\mathrm{P}$ (Olsen) en el suelo durante las diferentes etapas de los eventos de simulación de lluvia. El contenido nutricional (N, P, y K) para muestras de hierba Bermuda reflejó el efecto de las diferentes dosis de residuos de camada de pollos parrilleros. Se observó un mayor contenido nutricional en los tratamientos de 20 t/ha comparado con los de 6 t/ha. No obstante, los efectos solo fueron estadísticamente significativos para nitrógeno. El alum no parece ejercer un impacto significativo en el contenido nutricional de la yerba Bermuda, aunque se observaron disminuciones leves (no significativas) para $\mathrm{N}$ y $\mathrm{P}$ en el tratamiento de 20 tha de camada de pollos parrilleros con $20 \%$ de alum.

Palabras clave: simulación de lluvia, escorrentía, alum, calidad de agua, nutrientes, suelos tropicales 


\section{INTRODUCTION}

The sustainability of Puerto Rico's surface waters is being increasingly threatened by the continuous impact of contaminant loads from non-point sources of pollution. The Environmental Quality Board of Puerto Rico (PREQB) estimates that $70 \%$ of the river miles monitored are impaired, and $95 \%$ of the reservoir area does not meet water quality criteria for at least one of its designated uses (PREQB, 2008).

Agriculture is considered one of the leading sources of water pollution in the United States. It is estimated that agriculture affects $60 \%$ of impaired river miles and 50\% of impaired acres of reservoirs (Parry, 1998). Most of the impact attributed to agriculture comes from animal farm operations and their associated litter disposal practices. The problem with litter disposal has exacerbated in recent years because of a continuous trend from the production industry, in that the total number of farms have been drastically reduced while increasing production has been concentrating on a smaller number of very large farm operations. A survey by the USDA revealed that while the total number of animal farm operations declined from $1982(435,000)$ to $1997(213,000)$, the number of large size farms (more than 1,000 animal units) more than doubled during this period (USDA, 2001). As a result, litter nutrients (nitrogen and phosphorus) are being produced in concentrated areas at rates that cannot be fully absorbed by plant uptake. A USDA report indicates that 70\% of the 664,000 tons of recoverable litter phosphorus produced in 1997 was in excess of crop needs on farms (USDA, 2001).

Application of litter $\mathrm{P}$ in excess of crop needs results in the buildup of soil $\mathrm{P}$ to levels that may pose a threat to the surrounding waters (Sharpley, 2000). Martínez et al. (2002) conducted a survey on the nutritional status of 22 animal farm operations ( 11 dairy farms, 11 broiler farms) in Puerto Rico. Eighty percent ( $80 \%$ ) of the samples analyzed exceeded the critical agronomic soil test $\mathrm{P}$ level of $35 \mathrm{mg} / \mathrm{kg} \mathrm{P}$ (Olsen). Farms receiving broiler litter had significantly higher soil $P$ values $(150$ $\mathrm{mg} / \mathrm{kg}$ ) than those receiving cattle manure $(90 \mathrm{mg} / \mathrm{kg})$. In 2007 , OrtegaAchury et al. documented the extent of nutrient concentration losses in runoff from animal farm operations (broiler and dairy farms) under natural rainfall conditions. Results confirmed the high nutritional contaminant threat of broiler operations. Average runoff water composition for the broiler farm was $5.87,4.82$, and $4.12 \mathrm{mg} / \mathrm{L}$ for total P, dissolved $\mathrm{P}$, and total Kjeldahl nitrogen (TKN), respectively. The concentration of dissolved $\mathrm{P}$ exceeded $1 \mathrm{mg} / \mathrm{L}$ (a limit suggested by EPA to control $\mathrm{P}$ losses from agricultural lands) in all (100\%) the runoff events at the broiler farm. The results accentuate the need to implement an aggressive strategy to reduce $P$ export losses from these farms. 
During the last decade, the use of alum $\left[\mathrm{Al}_{2}\left(\mathrm{SO}_{4}\right)_{3} \cdot 14 \mathrm{H}_{2} \mathrm{O}\right]$ has surfaced as a potentially valuable best management practice (BMP) to reduce P losses from agricultural fields. Moore et al. (2000) reported a reduction of $73 \%$ of dissolved $\mathrm{P}$ concentrations in runoff from plots receiving alum-treated litter relative to that of the control. DeLaune et al. (2004) reported runoff concentration losses of $26 \mathrm{mg} \mathrm{P} / \mathrm{L}, 15.1 \mathrm{mg} \mathrm{P} /$ $\mathrm{L}, 13.4 \mathrm{mg} \mathrm{P} / \mathrm{L}$, and $0.88 \mathrm{mg} \mathrm{P} / \mathrm{L}$ for poultry litter amended with alum at rates of $0,5 \%, 10 \%$, and $20 \% \mathrm{w} / \mathrm{w}$, respectively. Reductions of runoff $\mathrm{P}$ concentrations between 50 and $90 \%$ have been reported from alumtreated litter fields (e.g., Sims and Luka-McCafferty, 2002; Smith et al., 2004; Warren et al., 2006). At the watershed level, Moore and Edwards (2007) reported a $340 \%$ higher cumulative P export loads from a watershed receiving normal litter (untreated) relative to those of a paired watershed receiving alum-treated litter. Alum has also shown to be effective in reducing ammonia volatilization from broiler litter, all of which promotes a healthier environment for birds and farm workers at broiler houses (Moore et al., 2000). The efficacy of alum in reducing $\mathrm{P}$ losses in runoff has yet to be evaluated under local conditions.

The objectives of this study are: 1) To evaluate the effect of different alum dosages on the extent of runoff nutrient concentration losses from soils amended with broiler litter; and 2) To evaluate the effect of rainfall frequency on runoff nutrient concentration losses from soils amended with broiler litter.

\section{MATERIALS AND METHODS}

A series of runoff simulations were conducted according to the guidelines of the National Research Project for Simulated Rainfall - indoor runoff box protocol (USDA-NRCS, 2001). A rainfall simulator similar to that described by Martínez et al. (2007) was used. Experiments were conducted at a rainfall intensity of $7 \mathrm{~cm} / \mathrm{h}$. Twenty-four (24) runoff boxes ( $1 \mathrm{~m}$ long, $20 \mathrm{~cm}$ wide, and $7.5 \mathrm{~cm}$ deep, with back walls $2.5 \mathrm{~cm}$ higher than the soil surface) were constructed out of galvanized sheet metal material. The boxes were filled with surface soil $(0$ to $7.5 \mathrm{~cm})$ of the Corozal (Aquic Haplohumult) series. After collection from the field, the soil was air dried, thoroughly mixed and passed through a $2 \mathrm{~mm}$ sieve. The boxes were packed with enough soil to achieve a final bulk density of about $1.1 \mathrm{~g} / \mathrm{cm}^{3}$. The boxes were left untreated for approximately one month to allow for soil stabilization. Intermittent wettingdrying cycles were applied through a mist sprinkler to speed up the stabilization process. Bermuda grass [Cynodon dactylon (L.)] seeds were broadcast over the experimental boxes to achieve greater than $70 \%$ grass coverage in all cases. 
Two broiler litter application rates were evaluated: $6 \mathrm{t} / \mathrm{ha}$, and $20 \mathrm{t} /$ ha. Prior to application, the specific manure dosage corresponding to each rate was mixed with alum at the following rates: 0 alum; $10 \% \mathrm{w} /$ $\mathrm{w}$ (i.e., $10 \mathrm{~g}$ of alum per $100 \mathrm{~g}$ of manure) (dry weight basis); and $20 \% \mathrm{w} /$ w. In addition, we evaluated a treatment consisting of $10 \% \mathrm{w} / \mathrm{w}$ alum + $24 \%(\mathrm{w} / \mathrm{w})$ Epson salt. The latter treatment is hypothesized to promote the formation of a hydrotalcite $\left[\mathrm{Mg}_{6} \mathrm{Al}_{2}\left(\mathrm{CO}_{3}\right)(\mathrm{OH})_{16} \cdot 4\left(\mathrm{H}_{2} \mathrm{O}\right)\right]$ type mineral that could in theory be as efficient as alum in reducing $\mathrm{P}$ losses from a field. Each combination of treatments was evaluated in triplicate for a total of 24 boxes (i.e., two litter rates $\mathrm{x}$ four amendments $\mathrm{x}$ three replicates). An absolute control treatment ( 0 litter, 0 alum) could not be included in this study because of limitations in runoff box availability. Said treatment was included in a companion study (Martínez et al., 2010). Broiler litter treatments were applied broadcast on top of the Bermuda grass (not incorporated) and were left settling for one month prior to the first rainfall simulation. Four simulation events were conducted at the following time intervals: 0 day (initial event), one, eight, and 30 days after the initial event.

On each simulation run, the boxes were placed on a metal frame inclined at a $20 \%$ slope to simulate field conditions. Simulated rainfall was applied until 30 minutes of runoff was produced from each box. Separate runoff aliquots $(100 \mathrm{~mL})$ were collected at $1,3,15$, and $30 \mathrm{~min}$ after runoff initiation. Samples were analyzed for total and dissolved $P$ (EPA method 365.4), TKN (EPA method 351.2), and $\mathrm{NO}_{3}-\mathrm{N}$ (EPA method 353.2) (USEPA, 1983). Samples for nitrate, and dissolved phosphorus were filtered through a $0.45-\mu \mathrm{m}$ Gelman acrodisc filter before analysis. The bulk runoff volume from each experimental tray was collected in a 19-L plastic container. In each case, time to runoff initiation and total runoff volume produced were measured.

Upon completion of all simulation events (30-day span), soil ( 0 to 7.5 $\mathrm{cm}$ ) and tissue samples were obtained from each tray. Soil samples (air dried and sieved) were analyzed for available P (Olsen) (Sims, 2000), and the tissue samples for total N, P, and K, at the Central Analytical Laboratory facility of the Agricultural Experiment Station at Río Piedras, Puerto Rico.

Statistical analyses were conducted by using the SAS® software program (SAS 9.1.3, SAS Institute, Cary, NC) using a model with three factors, namely, treatment, simulation date, and time after runoff initiation (TAR), and their interactions. In addition, random effects were included to model the split-split plot design (with treatment as main plot factor and date and TAR as the split and split-split factors, respectively). In all cases a transformation $[\operatorname{Ln}(y+1)]$ of the experimental data was used to achieve normality. 


\section{RESULTS AND DISCUSSION}

Although the mechanism for reducing $\mathrm{P}$ movement is still unclear, it is believed that alum is first hydrolyzed to an $\mathrm{Al}(\mathrm{OH})_{3}$ moiety which consequently adsorbs $\mathrm{P}$, thus forming an Al-P-OH amorphous mineral that limits $\mathrm{P}$ solubility in soils (Warren et al., 2006). Evidence in support of this mechanism is depicted by measurements of "soluble" $\left(\mathrm{CaCl}_{2}\right)$ extractable $\mathrm{P}$ in the litter matrix used in the different treatments (Table 1). The $20 \%$ alum rate resulted in significant reductions in "soluble" $P$ relative to that of the untreated ( 0 alum added) litter. The $6 \mathrm{t} / \mathrm{ha}$ and $20 \mathrm{t} / \mathrm{ha}$ treatments exhibited reductions of $43 \%$ and $75 \%$ in the "soluble" $P$ fraction relative to that of their untreated litter counterparts. In contrast, both the $10 \%$ alum rate and the alum + Epsom salt treatment resulted in increases in soluble $P$ relative to that of the untreated litter. This finding is possibly the result of the competing effect of the sulfate $\left(\mathrm{SO}_{4}{ }^{2}\right)$ anion added at these lower rate treatments (both in the $10 \%$ alum and alum+Epsom salt treatments) for phosphorus binding sites in litter. The sulfate ion will bind to $\mathrm{Ca}^{2+}$ and $\mathrm{Mg}^{2+}$ ions originally bound to phosphorus in the litter, thus forcing the phosphate anion into solution and in turn increasing the magnitude of the soluble $P$ fraction in those matrices. As the total amounts of alum added to the systems increase (i.e., $20 \%$ alum rate), aluminum forming minerals may begin to exert control of the solubility of phosphorus in the system, which results in significant reductions in $\mathrm{P}$ solubility. Additions of the alum-treated litter matrix resulted in lower application loads of soluble $\mathrm{P}$ to the soils compared to the loads from untreated litter (Table 1). At high alum rates, this reduction in soluble $\mathrm{P}$ loads is expected to result in a significant reduction of $\mathrm{P}$ transport in runoff.

The excellent soil phosphorus enrichment capacity of broiler litter is well recognized. The two application rates ( 6 and $20 \mathrm{t} / \mathrm{ha}$ without alum) resulted in increases in soil test $P$ levels of nearly 3.5 and 8 times the established agronomic criteria (i.e., $35 \mathrm{mg} / \mathrm{kg}$ ), respectively (Table 1). These application rates, which are common on broiler farms of Puerto Rico, result in excessive soil P buildups (Martínez et al., 2002). Over time, these areas become a primary source of phosphorus to surrounding waters under favorable transport conditions. Applications of alum reduced the resulting soil test $\mathrm{P}$ levels (Olsen) at both litter application rates, although the high variability between the individual experimental units prevented the results to be statistically significant. Nevertheless, the trend towards a reduction in labile $\mathrm{P}$ from soil receiving alumtreated litter applications is notable, particularly at the higher alum rate.

As expected, applications of poultry litter resulted in a nutrient-enriched runoff solution (Table 2). As stated, an absolute control treatment 
TABLE 1. Measurements of soluble $\left(\mathrm{CaCl}_{2}\right.$-extractable $) P$ in various treatments and resulting soil test $P$ levels.

\begin{tabular}{lccc}
\hline Treatment & $\begin{array}{c}\text { Soluble }\left(\mathrm{CaCl}_{2}\right) \\
\text { P in litter } \\
\text { matrix }\end{array}$ & $\begin{array}{c}\text { Soluble P added } \\
\text { (through litter) to } \\
\text { experimental units }\end{array}$ & $\begin{array}{c}\text { Soil test P } \\
\text { levels (Olsen) } \\
(\mathrm{mg} / \mathrm{kg})\end{array}$ \\
\hline Control - no litter (unamended soil) & N/A & N/A & $12.3 \mathrm{c}$ \\
$6 \mathrm{t} / \mathrm{ha}$ - no alum & $210.0 \mathrm{c}^{1}$ & $22.9 \mathrm{f}$ & $118.2 \mathrm{abc}$ \\
$6 \mathrm{t} / \mathrm{ha}-10 \%$ alum & $288.2 \mathrm{~b}$ & $34.6 \mathrm{e}$ & $28.8 \mathrm{bc}$ \\
$6 \mathrm{t} / \mathrm{ha}-20 \%$ alum & $120.5 \mathrm{~d}$ & $15.4 \mathrm{~h}$ & $27.1 \mathrm{bc}$ \\
$6 \mathrm{t} / \mathrm{ha}-10 \%$ alum + Epsom salt & $351.0 \mathrm{a}$ & $51.2 \mathrm{~d}$ & $116.9 \mathrm{abc}$ \\
$20 \mathrm{t} / \mathrm{ha}-$ no alum & $210.0 \mathrm{c}$ & $76.2 \mathrm{c}$ & $276.8 \mathrm{ab}$ \\
$20 \mathrm{t} / \mathrm{ha}-10 \%$ alum & $246.5 \mathrm{c}$ & $96.6 \mathrm{~b}$ & $262.9 \mathrm{abc}$ \\
$20 \mathrm{t} / \mathrm{ha}-20 \%$ alum & $53.3 \mathrm{e}$ & $22.4 \mathrm{~g}$ & $93.7 \mathrm{bc}$ \\
$20 \mathrm{t} / \mathrm{ha}-10 \%$ alum + Epsom salt & $352.3 \mathrm{a}$ & $168.7 \mathrm{a}$ & $355.3 \mathrm{a}$ \\
\hline
\end{tabular}

${ }^{1}$ Within a column, means followed by the same letter are not different at the $\alpha=0.05$ level of probability according to a LSD test.

TABLE 2. Nutrient concentration in runoff water. Results represent mean values across dates and times after runoff initiation.

\begin{tabular}{lccccc}
\hline $\begin{array}{l}\text { Treatment } \\
\text { (litter + alum rates) }\end{array}$ & $\begin{array}{c}\mathrm{TP} \\
(\mathrm{mg} / \mathrm{L})\end{array}$ & $\begin{array}{c}\mathrm{DP} \\
(\mathrm{mg} / \mathrm{L})\end{array}$ & $\begin{array}{c}\mathrm{DP} / \mathrm{TP} \\
(\%)\end{array}$ & $\begin{array}{c}\mathrm{NO}_{3}-\mathrm{N} \\
(\mathrm{mg} / \mathrm{L})\end{array}$ & $\begin{array}{c}\mathrm{TKN} \\
(\mathrm{mg} / \mathrm{L})\end{array}$ \\
\hline $6 \mathrm{t} / \mathrm{ha}-$ no alum & $2.59 \mathrm{~b} \mathrm{~b}^{1}$ & $0.70 \mathrm{~cd}$ & $14.82 \mathrm{~b}$ & $1.39 \mathrm{~b}$ & $1.16 \mathrm{e}$ \\
$6 \mathrm{t} / \mathrm{ha}-10 \%$ alum & $2.34 \mathrm{~b}$ & $0.46 \mathrm{~cd}$ & $17.98 \mathrm{~b}$ & $1.01 \mathrm{~b}$ & $1.39 \mathrm{e}$ \\
$6 \mathrm{t} / \mathrm{ha}-20 \%$ alum & $2.00 \mathrm{~b}$ & $0.34 \mathrm{~d}$ & $14.76 \mathrm{~b}$ & $1.42 \mathrm{~b}$ & $1.38 \mathrm{e}$ \\
$6 \mathrm{t} / \mathrm{ha}-10 \%$ alum + Epsom salt & $2.39 \mathrm{~b}$ & $0.57 \mathrm{~cd}$ & $20.57 \mathrm{ab}$ & $1.26 \mathrm{~b}$ & $1.44 \mathrm{de}$ \\
$20 \mathrm{t} / \mathrm{ha}-$ no alum & $6.10 \mathrm{a}$ & $3.55 \mathrm{a}$ & $52.55 \mathrm{a}$ & $3.21 \mathrm{a}$ & $2.33 \mathrm{~cd}$ \\
$20 \mathrm{t} / \mathrm{ha}-10 \%$ alum & $5.54 \mathrm{a}$ & $1.50 \mathrm{bc}$ & $20.26 \mathrm{ab}$ & $3.21 \mathrm{a}$ & $2.87 \mathrm{bc}$ \\
$20 \mathrm{t} / \mathrm{ha}-20 \%$ alum & $2.94 \mathrm{~b}$ & $1.06 \mathrm{bcd}$ & $34.62 \mathrm{ab}$ & $3.21 \mathrm{a}$ & $3.63 \mathrm{ab}$ \\
$20 \mathrm{t} / \mathrm{ha}-10 \%$ alum + Epsom salt & $4.89 \mathrm{a}$ & $1.98 \mathrm{ab}$ & $38.63 \mathrm{ab}$ & $3.67 \mathrm{a}$ & $5.11 \mathrm{a}$ \\
\hline
\end{tabular}

${ }^{1}$ Within a column, means followed by the same letter are not different at the $\alpha=0.05$ level of probability according to a LSD test.

( 0 litter, 0 alum) could not be included in this study because of limitations in runoff boxes. However, average TP and DP concentrations in runoff obtained for an absolute control treatment included in a companion study (using the same soil at $\geq 80 \%$ grass cover) were $0.57 \mathrm{mg} / \mathrm{L}$ and $0.006 \mathrm{mg}$ / L, respectively (Martínez et al., 2010). These concentrations are similar to the results obtained by Ramírez-Ávila (2005) under field conditions for the same soil, namely, $0.41 \mathrm{mg} / \mathrm{L}$ and $0.08 \mathrm{mg} / \mathrm{L}$ for TP and DP, respectively. These values are at least four times lower than the average concentrations obtained at the lowest litter rate ( $6 \mathrm{t} / \mathrm{ha}$ ) in this study.

Both litter application rates (i.e., 6 and 20 t/ha without alum) resulted in elevated total phosphorus (TP) concentrations in the runoff 
water. However, runoff concentration losses in the $20 \mathrm{t} /$ ha treatment were approximately twice as high as those of the $6 \mathrm{t} / \mathrm{ha}$ treatment (Table 2). The value obtained for the $20 \mathrm{t} /$ ha-no alum treatment $(6.10 \mathrm{mg} \mathrm{P} /$ $\mathrm{L}$ ) is similar to the value reported by Ortega-Achury et al. (2007) from a broiler farm of Puerto Rico under natural rainfall (i.e., $5.87 \mathrm{mg} \mathrm{TP} / \mathrm{L}$ ). The effectiveness of alum in reducing TP losses was more evident at the highest litter rate and alum dosage (i.e., 20 t/ha litter $+20 \%$ alum). A $52 \%$ reduction (as compared to no-alum treatment) in the concentration of TP in runoff was observed at that treatment combination $(20 \mathrm{t} /$ $\mathrm{ha}+20 \%$ alum). Although in general there is a trend for the other alum treatments to reduce the concentration of TP in the runoff waters, the effects were not statistically significant $(\alpha=0.05)$.

The greatest impact of alum was on the reduction of dissolved $\mathrm{P}$ losses in runoff. Only at the highest litter rate with $10 \%$ alum added did the dissolved P concentrations slightly exceed the $1 \mathrm{mg} / \mathrm{L}$ threshold value suggested as a potential control limit for agricultural non-point sources (Parry, 1998) (Table 2). Concentration losses at that rate (20 t/ ha) for the no alum treatment were significantly higher than those of all alum treatments (except the $20 \mathrm{t} / \mathrm{ha}+\mathrm{MgSO}_{4}$ treatment), and similar to the value (i.e., $4.82 \mathrm{mg} / \mathrm{L}$ ) reported by Ortega-Achury et al. (2007) for a broiler farm under similar litter application rates. The $10 \%$ and $20 \%$ alum treatments at $20 \mathrm{t} /$ ha litter rate resulted in reductions of $58 \%$ and $70 \%$ of the DP concentrations in runoff, respectively. These percentage reductions in DP concentration losses are in accordance with results from similar studies in the U.S. (Moore et al., 2000; Sims and Luka-McCafferty, 2002; Smith et al., 2004; Warren et al., 2006).

In the case of the $20 \%$ alum treatment, the resulting DP concentration values would comply with the $1 \mathrm{mg} / \mathrm{L}$ threshold limit proposed. At the lowest litter application rate $(6 \mathrm{t} / \mathrm{ha})$, all treatments containing alum showed a tendency towards a reduction in DP concentration losses relative to the no alum treatment. However, the results were not statistically significant (Table 2 ).

A highly positive correlation $(r>0.80)$ was observed between TP and DP concentrations in runoff in all treatments except those containing exclusively alum at the $20 \mathrm{t} / \mathrm{ha}$ litter rate, and the $20 \%$ alum treatment at $6 \mathrm{t} /$ ha litter rate (Figure 1). This finding suggests that alum additions modified the soil-litter matrix significantly enough to alter the equilibrium reactions governing the relationship between TP and DP observed in the unamended litter treatments.

Total $\mathrm{P}$ losses in runoff were positively correlated to both the amount of $\mathrm{CaCl}_{2}$-extractable $\mathrm{P}$ added initially to the soils, and to the soil test P (STP) levels (Olsen) determined at the end of the experiment (Figure 2). In general, STP was a better predictor of total P concentra- 

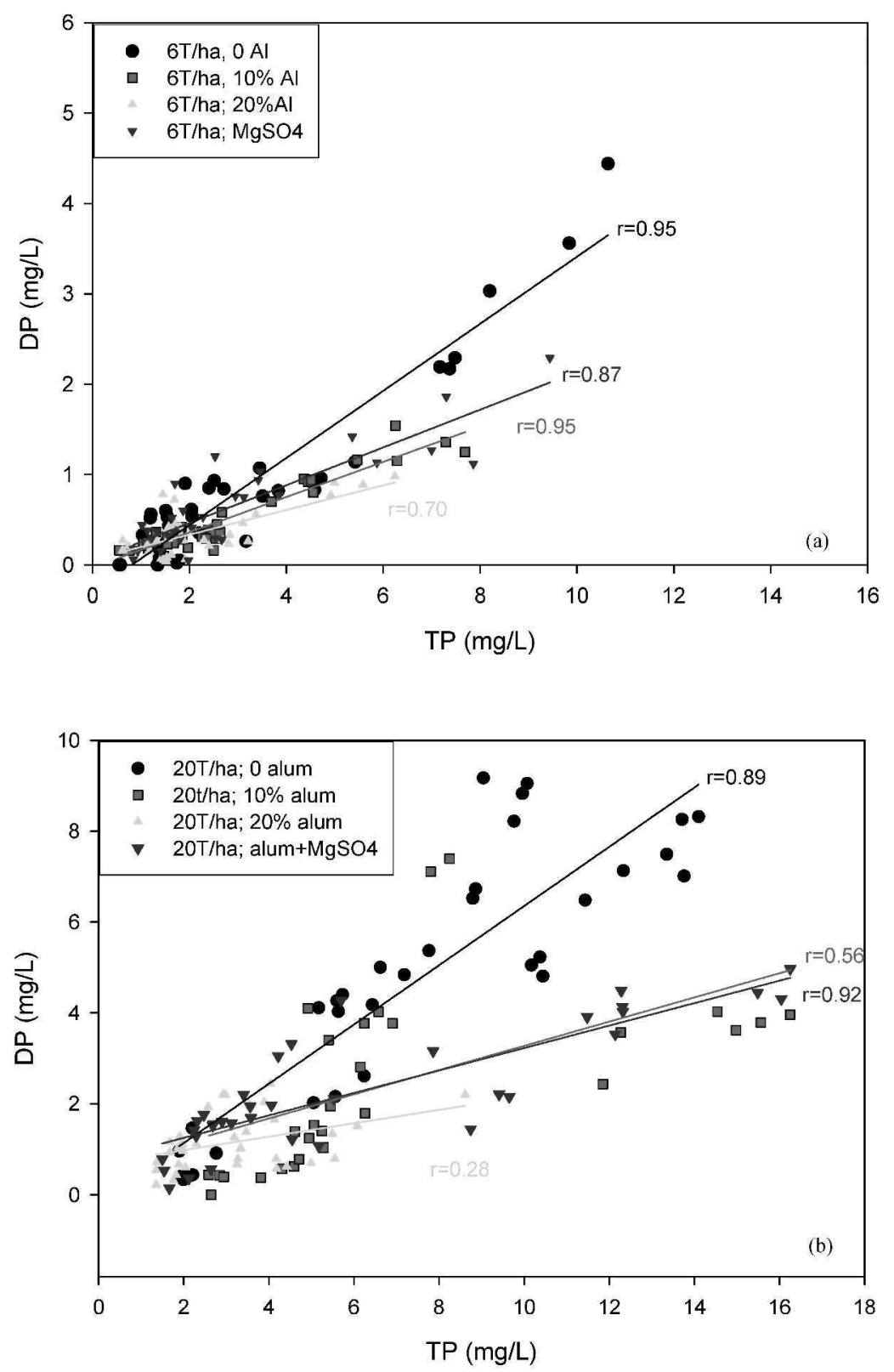

FIGURE 1. Effect of litter rate on the relationship between total phosphorus and dissolved phosphorus on an Ultisol of Puerto Rico: a) $6 \mathrm{t} / \mathrm{ha}$, and b) 20 t/ha. Data included from all rainfall simulation events. 
50 MARTÍNEZ-RoDRÍGUEZ ET AL./ BROILER LITTER AMENDED SOILS
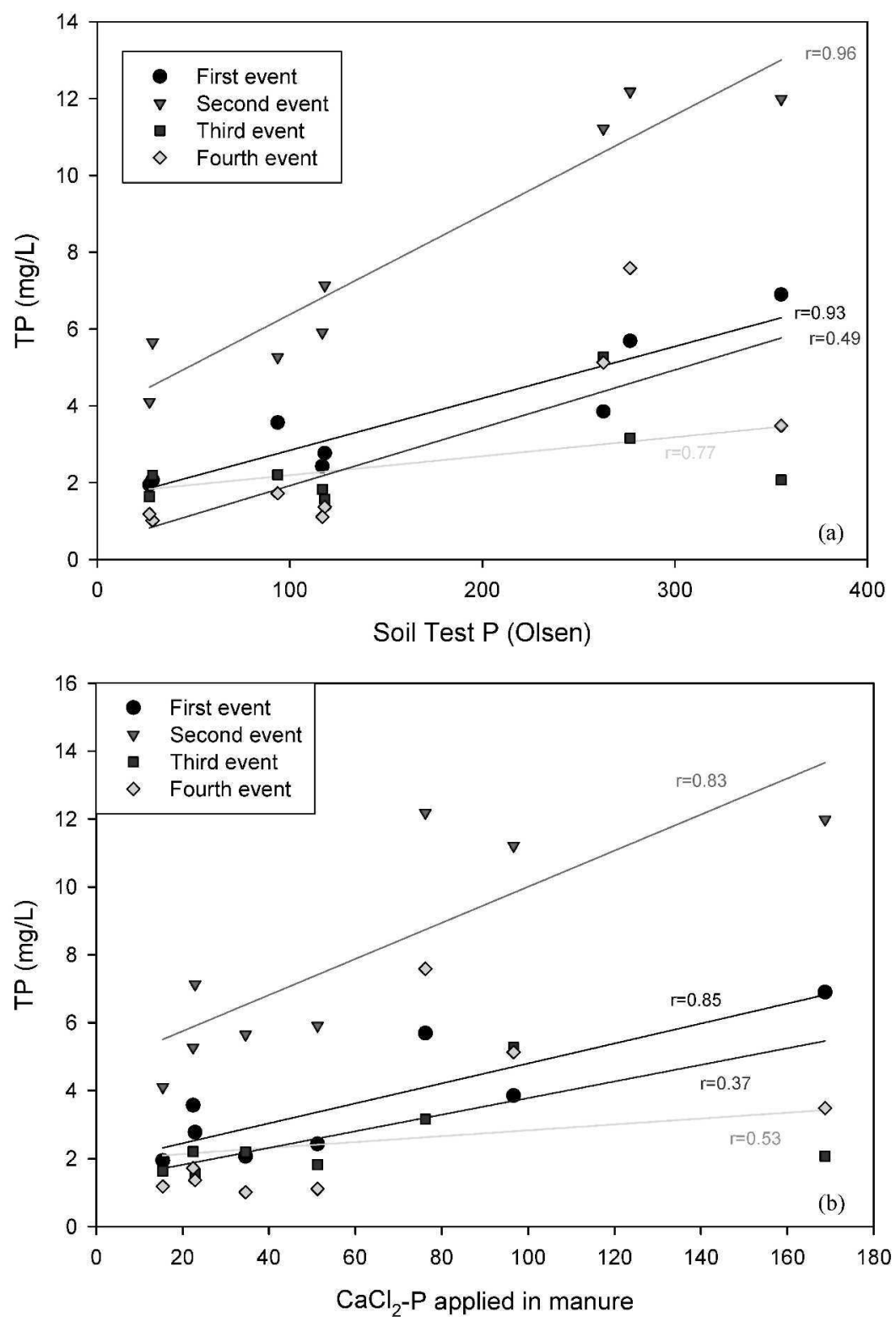

FIGURE 2. Relationship between soil available $\mathrm{P}$ and total phosphorus concentrations in runoff water: a) Olsen $P$ levels determined at the end of experiment; b) amount of soluble $\mathrm{P}\left(\mathrm{CaCl}_{2}-\mathrm{P}\right)$ applied initially to the soil through broiler litter amendment. Pearson correlation coefficients $(r)$ are included for all relationships. 
tion losses. The relationships weakened with time which is expected because of the multiple transformation reactions occurring in the soil. Various scientists have reported a highly positive correlation between TP concentration losses in runoff and either soil test $\mathrm{P}$ or soluble $\mathrm{P}$ in litter in accord with the results presented herein (Smith et al., 2004; DeLaune et al., 2004; Moore and Edwards, 2007).

Contrary to TP, DP concentration losses in runoff were not correlated with either the $\mathrm{CaCl}_{2}-\mathrm{P}$ fraction of the litter matrix or with soil test $\mathrm{P}$ levels in almost any of the rainfall events conducted. Only at the second simulated rainfall event were DP losses moderately correlated to soil test $\mathrm{P}(\mathrm{r}=0.60 ; \mathrm{p}=0.004)$ (Figure $3 \mathrm{a})$. This event represented high runoff conditions (see below) in which the infiltration capacity of the soils was exceeded. An evaluation of the results from all sampling events combined denotes a marked difference between the DP concentrations resulting from the untreated litter compared to those from the alum treatments, particularly at soil $\mathrm{P}$ values $>100 \mathrm{mg} \mathrm{P} / \mathrm{kg}$ (Figure $3 b$ ). This finding once again evidences the effect of alum in reducing the solubility of $\mathrm{P}$ from the litter matrix.

Nitrate and total Kjeldahl nitrogen (TKN) losses varied according to the litter application rates, with higher losses observed for the $20 \mathrm{t} / \mathrm{ha}$ litter rate than for the $6 \mathrm{t} / \mathrm{ha}$ rate (Table 2). In the case of nitrate, alum additions did not exert a significant effect at either litter rate. For TKN, however, alum additions at the highest litter rate exhibited higher concentration losses with the effects being statistically significant for the $20 \%$ alum treatment and the treatment consisting of a mixture of alum and Epsom salt (Table 2). These results are consistent with the general effect reported by alum additions in regard to its tendency to reduce $\mathrm{N}$ volatilization losses and thus to produce litter with a higher $\mathrm{N}$ content (Moore and Edwards, 2007). A highly positive correlation ( $r>0.65 ; p<$ 0.001 ) was observed between TKN and nitrate concentration losses in all cases, except in the second simulated rainfall event (data not shown). On the other hand, TKN losses were positively correlated with "soluble" $\left(\mathrm{CaCl}_{2}\right.$-extractable) $\mathrm{P}$ in litter in all events, except in the one conducted eight days after the initial event (i.e., third event).

\section{Effect of date of simulation on nutrient concentration losses}

As previously stated, four rainfall simulation events were conducted on separate dates, namely, 0 day (initial event), one, eight, and 30 days after initial event. This experimental set-up had an obvious impact on the soil moisture content and in turn on the amount of runoff generated at each event. Table 3 shows average results of two important diagnostic variables: time to runoff initiation (that is, the time 

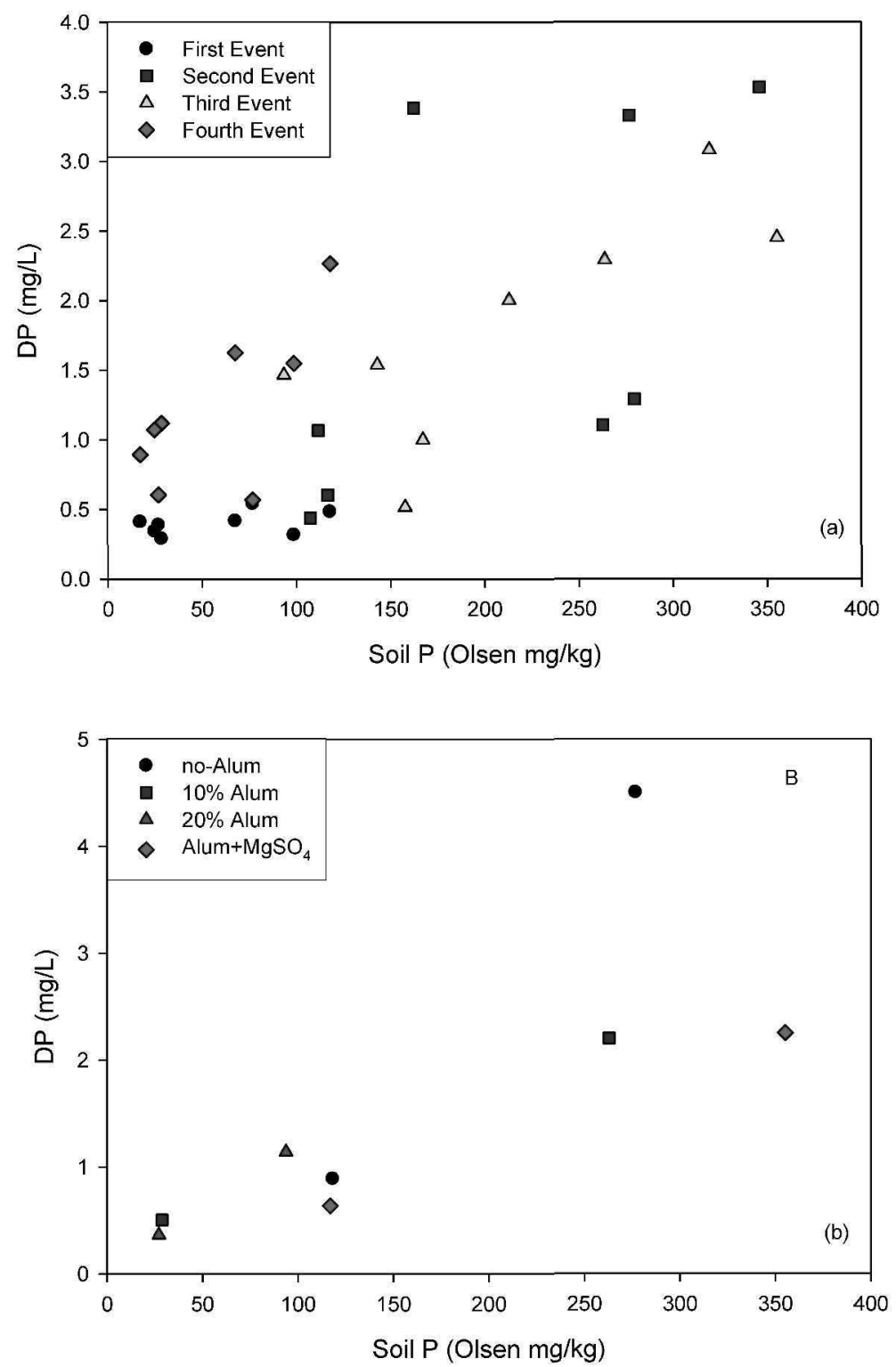

FIGURE 3. Relationship between soil available (Olsen) P and dissolved phosphorus concentrations in runoff water: a) each data point represents the average of three replicates for all treatments; b) mean values for the control ( 0 alum), and alum containing treatments. Pearson correlation coefficients (r) for all relationships are included. 
TABLE 3. Effect of rainfall simulation date on time to runoff initiation and total runoff volume produced. Results are mean for all experimental units.

\begin{tabular}{lrr}
\hline Days after initial event & $\begin{array}{c}\text { Time to runoff initiation } \\
\text { (minutes) }\end{array}$ & $\begin{array}{c}\text { Total runoff produced } \\
(\mathrm{ml})\end{array}$ \\
\hline 0 (initial event) & $9.96 \mathrm{~b}$ & $1,554 \mathrm{~b}$ \\
1 & $0.75 \mathrm{c}$ & $3,960 \mathrm{a}$ \\
8 & $19.76 \mathrm{a}$ & $989 \mathrm{c}$ \\
30 & $12.23 \mathrm{~b}$ & $1,947 \mathrm{~b}$ \\
\hline
\end{tabular}

${ }^{1}$ Within a column, means followed by the same letter are not different at the $\alpha=0.05$ level of probability according to a LSD test.

lapse between rainfall initiation and the start of runoff), and total runoff volume produced. It is evident that successive rainfall events, such as the one conducted 24 hours after the initial event, generate significantly higher runoff volumes since the soils have usually exceeded their infiltration capacity at the onset of said rainfall event. This type of event, typical of the rainy season, provides a favorable scenario for off-field nutrient transport and therefore requires special consideration.

Recent advances in molecular spectroscopy techniques have allowed scientists to characterize the molecular environment of different species in heterogeneous samples such as litters. The surfacing evidence has confronted scientists with the need to revise old paradigms in terms of the mechanisms which control species availability and mobility in the environment. Such is the case with the dynamics of phosphorus in broiler litter. The conventional knowledge is that organic forms control phosphorus availability through mineralization reactions. However, recent evidence indicates that broiler litter is mainly composed of sparingly soluble calcium and magnesium phosphate minerals that control soil solution P concentrations (Cooperband and Ward, 2002; Sato et al., 2005). Sato et al. (2005) stated that close to half of the total $\mathrm{P}$ in litter is characterized by free and weakly bound phosphate. These findings minimize the role of organic-P forms in controlling phosphorus mobility from fields amended with broiler litter.

This new conceptual framework allows us to explain the response pattern of phosphorus concentration in runoff for simulation events performed on different dates. As stated previously, the second rainfall event was conducted just 24 hours after the initial one under conditions near to soil saturation. As a result, greater runoff volume was generated and with it a greater possibility for transport of suspended sediment and litter particulates (this aspect was evaluated in detail in the accompanying study on this issue). A significant increase in TP concen- 
tration in runoff was observed at that date for all treatments, except for the treatment containing $20 \%$ alum at the higher litter rate (Table 4). It is important to recognize that the combination of an increased runoff volume with higher TP concentrations would amount to extensive export loads for the receiving waters. Thus, from a management perspective, reducing TP concentration losses from events such as this deserves the highest priority. Increases in TP concentrations were approximately twice the value observed in the first event for all treatments except for the one containing $20 \%$ alum at the highest litter rate. In the latter treatment, the observed concentration was nearly half the value observed for the other treatments at a similar litter rate (20 t/ha). Dissolved P losses followed a pattern similar to that of TP, with significantly higher concentrations on the second simulation date than on the first event (Table 5). In this case the exceptions were the treatments containing 20\% alum and those containing Epsom salt. It is important to emphasize that DP losses from the treatment containing $20 \%$ alum would meet the $1 \mathrm{mg} / \mathrm{L}$ threshold value in almost all instances at either litter rate. In fact, average DP concentrations for the critical 24-hour rainfall event were $85 \%$ lower at the $20 \%$ alum treatment than at the treatment containing no alum.

Nitrate losses exhibited a pattern more similar to the one that would be expected from an organic substrate (Table 6). There was an initial high flush of nitrate associated with the first rainfall event, with practically all treatments exhibiting higher concentration losses at that date. Nitrate losses at the $6 \mathrm{t} /$ ha litter rate never reached first rainfall event levels on subsequent events, thus implying that a significant portion of the source of nitrate (broiler litter) had been removed through runoff, and/or that there was a time lag in the mineralization process that prevented further buildups of nitrate. In contrast, treatments at the $20 \mathrm{t} / \mathrm{ha}$ exhibited a surge in nitrate concentration at the last rainfall event, supporting the conjecture that a combination of factors was responsible for the behavior observed at the lower litter rate. In general, TKN losses exhibited a behavior similar to that of nitrate (Table 7).

\section{Effect of alum treatments on nutritional content of Bermuda grass}

The nutritional concentration ( $\mathrm{N}, \mathrm{P}$, and $\mathrm{K}$ ) of the Bermuda grass samples reflected the effect of broiler litter rate (Table 8 ). Higher nutritional concentrations were generally observed at the 20 tha treatments in comparison with those at the $6 \mathrm{t}$ /ha rate. However, the effects were statistically significant only for nitrogen. Alum did not seem to exert a significant impact on the nutritional concentration of the grass, 
TABLE 4. Mean total phosphorus concentration $(m g / L)$ in runoff for the different rainfall simulation events.

\begin{tabular}{|c|c|c|c|c|c|c|c|c|}
\hline Simulation Date & $\begin{array}{c}6 \mathrm{t} / \mathrm{ha} \\
\text { no alum }\end{array}$ & $\begin{array}{l}6 \mathrm{t} / \mathrm{ha}+10 \% \\
\text { alum }\end{array}$ & $\begin{array}{l}6 \mathrm{t} / \mathrm{ha}+20 \% \\
\text { alum }\end{array}$ & $\begin{array}{c}6 \mathrm{t} / \mathrm{ha}+10 \% \\
\text { alum }+ \text { Epsom salt }\end{array}$ & $\begin{array}{l}20 \text { t/ha } \\
\text { no alum }\end{array}$ & $\begin{array}{c}20 \mathrm{t} / \mathrm{ha}+10 \% \\
\text { alum }\end{array}$ & $\begin{array}{c}20 \mathrm{t} / \mathrm{ha}+20 \% \\
\text { alum }\end{array}$ & $\begin{array}{c}20 \mathrm{t} / \mathrm{ha}+10 \% \\
\text { alum + Epsom salt }\end{array}$ \\
\hline 0 (initial event) & $2.63 \mathrm{~b}^{1}$ & $2.02 \mathrm{~b}$ & $1.92 \mathrm{~b}$ & $2.38 \mathrm{~b}$ & $5.04 \mathrm{~b}$ & $3.60 \mathrm{~b}$ & $3.56 \mathrm{a}$ & $6.12 \mathrm{~b}$ \\
\hline 1 & $6.82 \mathrm{a}$ & $5.54 \mathrm{a}$ & $3.96 \mathrm{a}$ & $5.60 \mathrm{a}$ & $12.10 \mathrm{a}$ & $10.22 \mathrm{a}$ & 5.14 a & $11.62 \mathrm{a}$ \\
\hline 8 & $1.48 \mathrm{c}$ & $2.14 \mathrm{~b}$ & $1.63 \mathrm{~b}$ & $1.81 \mathrm{bc}$ & $2.80 \mathrm{c}$ & $5.02 \mathrm{~b}$ & $2.17 \mathrm{~b}$ & $2.08 \mathrm{c}$ \\
\hline 30 & $1.36 \mathrm{c}$ & $0.99 \mathrm{c}$ & $1.14 \mathrm{~b}$ & $1.10 \mathrm{c}$ & $7.44 \mathrm{~b}$ & $4.89 \mathrm{~b}$ & $1.71 \mathrm{~b}$ & $3.36 \mathrm{c}$ \\
\hline
\end{tabular}

${ }^{1}$ Within a column, means followed by the same letter are not different at the $\alpha=0.05$ level of probability according to a LSD test.

TABLE 5. Mean dissolved phosphorus concentration $(m g / L)$ in runoff for the different rainfall simulation events.

\begin{tabular}{|c|c|c|c|c|c|c|c|c|}
\hline Simulation Date & $\begin{array}{c}6 \mathrm{t} / \mathrm{ha} \\
\text { no alum }\end{array}$ & $\begin{array}{l}6 \mathrm{t} / \mathrm{ha}+10 \% \\
\text { alum }\end{array}$ & $\begin{array}{l}6 \mathrm{t} / \mathrm{ha}+20 \% \\
\text { alum }\end{array}$ & $\begin{array}{c}6 \mathrm{t} / \mathrm{ha}+10 \% \\
\text { alum }+ \text { Epsom salt }\end{array}$ & $\begin{array}{l}20 \text { tha } \\
\text { no alum }\end{array}$ & $\begin{array}{c}20 \text { tha }+10 \% \\
\text { alum }\end{array}$ & $\begin{array}{c}20 \text { tha }+20 \% \\
\text { alum }\end{array}$ & $\begin{array}{c}20 \mathrm{t} / \mathrm{ha}+10 \% \\
\text { alum }+ \text { Epsom salt }\end{array}$ \\
\hline 0 (initial event) & $0.43 \mathrm{~b}^{1}$ & $0.29 \mathrm{~b}$ & $0.38 \mathrm{a}$ & $0.56 \mathrm{ab}$ & $2.44 \mathrm{~b}$ & $0.51 \mathrm{~b}$ & $1.40 \mathrm{a}$ & $2.24 \mathrm{a}$ \\
\hline 1 & $2.05 \mathrm{a}$ & $1.11 \mathrm{a}$ & $0.58 \mathrm{a}$ & $1.24 \mathrm{a}$ & $6.53 \mathrm{a}$ & $2.57 \mathrm{a}$ & 0.95 a & $3.21 \mathrm{a}$ \\
\hline 8 & $0.45 \mathrm{~b}$ & $0.39 \mathrm{~b}$ & $0.29 \mathrm{a}$ & $0.40 \mathrm{~b}$ & $1.44 \mathrm{~b}$ & $1.42 \mathrm{a}$ & $1.11 \mathrm{a}$ & $0.79 \mathrm{~b}$ \\
\hline 30 & $0.31 \mathrm{~b}$ & $0.21 \mathrm{~b}$ & $0.16 \mathrm{a}$ & $0.24 \mathrm{~b}$ & $5.79 \mathrm{a}$ & $1.99 \mathrm{a}$ & $0.82 \mathrm{a}$ & $2.24 \mathrm{a}$ \\
\hline
\end{tabular}

${ }^{1}$ Within a column, means followed by the same letter are not different at the $\alpha=0.05$ level of probability according to a LSD test. 
TABLE 6. Mean $\mathrm{NO}_{3}-\mathrm{N}$ concentrations $(\mathrm{mg} / \mathrm{L})$ in runoff for the different rainfall simulation events.

\begin{tabular}{|c|c|c|c|c|c|c|c|c|}
\hline Simulation Date & $\begin{array}{c}6 \mathrm{t} / \mathrm{ha} \\
\text { no alum }\end{array}$ & $\begin{array}{l}6 \mathrm{t} / \mathrm{ha}+10 \% \\
\text { alum }\end{array}$ & $\begin{array}{l}6 \mathrm{t} / \mathrm{ha}+20 \% \\
\text { alum }\end{array}$ & $\begin{array}{c}6 \mathrm{t} / \mathrm{ha}+10 \% \\
\text { alum +Epsom salt }\end{array}$ & $\begin{array}{l}20 \text { t/ha } \\
\text { no alum }\end{array}$ & $\begin{array}{c}20 \mathrm{t} / \mathrm{ha}+10 \% \\
\text { alum }\end{array}$ & $\begin{array}{c}20 \mathrm{t} / \mathrm{ha}+20 \% \\
\text { alum }\end{array}$ & $\begin{array}{c}20 \mathrm{t} / \mathrm{ha}+10 \% \\
\text { alum + Epsom salt }\end{array}$ \\
\hline 0 (initial event) & $2.74 \mathbf{a}^{1}$ & $2.09 \mathrm{a}$ & $2.80 \mathrm{a}$ & $3.16 \mathrm{a}$ & $3.47 \mathrm{a}$ & $3.94 \mathrm{a}$ & $6.45 \mathrm{a}$ & $5.41 \mathrm{a}$ \\
\hline 1 & $1.64 \mathrm{ab}$ & $0.93 \mathrm{~b}$ & $1.26 \mathrm{~b}$ & $1.13 \mathrm{~b}$ & $4.20 \mathrm{a}$ & $1.97 \mathrm{~b}$ & $1.88 \mathrm{~b}$ & $2.13 \mathrm{c}$ \\
\hline 8 & $0.85 \mathrm{~b}$ & $0.68 \mathrm{~b}$ & $1.01 \mathrm{~b}$ & $0.59 \mathrm{~b}$ & $1.35 \mathrm{~b}$ & $2.80 \mathrm{ab}$ & $2.49 \mathrm{~b}$ & $3.21 \mathrm{bc}$ \\
\hline 30 & $0.78 \mathrm{~b}$ & $0.64 \mathrm{~b}$ & $0.98 \mathrm{~b}$ & $0.87 \mathrm{~b}$ & $4.76 \mathrm{a}$ & $4.64 \mathrm{a}$ & $3.20 \mathrm{~b}$ & $4.65 \mathrm{ab}$ \\
\hline
\end{tabular}

${ }^{1}$ Within a column, means followed by the same letter are not different at the $\alpha=0.05$ level of probability according to a LSD test.

TABLE 7. Mean TKN concentrations ( $m g / L$ ) in runoff for the different rainfall simulation events.

\begin{tabular}{|c|c|c|c|c|c|c|c|c|}
\hline Simulation Date & $\begin{array}{c}6 \mathrm{t} / \mathrm{ha} \\
\text { no alum }\end{array}$ & $\begin{array}{c}6 \mathrm{t} / \mathrm{ha}+10 \% \\
\text { alum }\end{array}$ & $\begin{array}{l}6 \mathrm{t} / \mathrm{ha}+20 \% \\
\text { alum }\end{array}$ & $\begin{array}{c}6 \mathrm{t} / \mathrm{ha}+10 \% \\
\text { alum }+ \text { Epsom salt }\end{array}$ & $\begin{array}{l}20 \text { t/ha } \\
\text { no alum }\end{array}$ & $\begin{array}{c}20 \mathrm{t} / \mathrm{ha}+10 \% \\
\text { alum }\end{array}$ & $\begin{array}{l}20 \mathrm{t} / \mathrm{ha}+20 \% \\
\text { alum }\end{array}$ & $\begin{array}{c}20 \mathrm{t} / \mathrm{ha}+10 \% \\
\text { alum +Epsom salt }\end{array}$ \\
\hline 0 (initial event) & $1.65 \mathrm{a}^{1}$ & $1.95 \mathrm{a}$ & $2.35 \mathrm{a}$ & $2.32 \mathrm{a}$ & $2.61 \mathrm{~b}$ & $2.92 \mathrm{ab}$ & $7.65 \mathrm{a}$ & $10.92 \mathrm{a}$ \\
\hline 1 & $1.53 \mathrm{ab}$ & $2.02 \mathrm{a}$ & $1.81 \mathrm{a}$ & $1.89 \mathrm{a}$ & $4.19 \mathrm{a}$ & $4.23 \mathrm{a}$ & $3.08 \mathrm{~b}$ & $7.08 \mathrm{~b}$ \\
\hline 8 & $0.74 \mathrm{c}$ & $0.99 \mathrm{~b}$ & $0.79 \mathrm{~b}$ & $0.85 \mathrm{~b}$ & $0.89 c$ & $2.00 \mathrm{~b}$ & $2.57 \mathrm{~b}$ & $2.37 \mathrm{c}$ \\
\hline 30 & $0.85 \mathrm{bc}$ & $0.83 \mathrm{~b}$ & $0.91 \mathrm{~b}$ & $1.00 \mathrm{~b}$ & $2.49 \mathrm{~b}$ & $2.65 \mathrm{~b}$ & $2.65 \mathrm{~b}$ & $3.29 \mathrm{c}$ \\
\hline
\end{tabular}

${ }^{1}$ Within a column, means followed by the same letter are not different at the $\alpha=0.05$ level of probability according to a LSD test. 
TABLE 8. Nutrient concentration of Bermuda grass samples at harvest.

\begin{tabular}{llll}
\hline Treatment & $\mathrm{N}(\%)$ & $\mathrm{P}(\%)$ & $\mathrm{K}(\%)$ \\
\hline $6 \mathrm{t} / \mathrm{ha}-$ no alum & $2.04 \mathrm{~b}^{1}$ & $0.38 \mathrm{a}$ & $3.56 \mathrm{a}$ \\
$6 \mathrm{t} / \mathrm{ha}-10 \%$ alum & $2.19 \mathrm{~b}$ & $0.43 \mathrm{a}$ & $3.79 \mathrm{a}$ \\
$6 \mathrm{t} / \mathrm{ha}-20 \%$ alum & $2.26 \mathrm{~b}$ & $0.37 \mathrm{a}$ & $4.05 \mathrm{a}$ \\
$6 \mathrm{t} / \mathrm{ha}-10 \%$ alum + Epsom salt & $2.04 \mathrm{~b}$ & $0.41 \mathrm{a}$ & $3.58 \mathrm{a}$ \\
$20 \mathrm{t} / \mathrm{ha}-$ no alum & $3.04 \mathrm{a}$ & $0.54 \mathrm{a}$ & $4.08 \mathrm{a}$ \\
$20 \mathrm{t} / \mathrm{ha}-10 \%$ alum & $3.22 \mathrm{a}$ & $0.47 \mathrm{a}$ & $4.72 \mathrm{a}$ \\
20 tha $-20 \%$ alum & $2.90 \mathrm{a}$ & $0.38 \mathrm{a}$ & $4.57 \mathrm{a}$ \\
20 t/ha $-10 \%$ alum + Epsom salt & $3.08 \mathrm{a}$ & $0.54 \mathrm{a}$ & $4.70 \mathrm{a}$ \\
\hline
\end{tabular}

${ }^{1}$ Within a column, means followed by the same letter are not different at the $\alpha=0.05$ level of probability according to a LSD test.

although a slight decrease (non significant) in both $\mathrm{N}$ and $\mathrm{P}$ was observed at the $20 \%$ alum rate for the $20 \mathrm{t}$ /ha litter rate. A slight decrease in $\mathrm{P}$ content would be consistent with a reduction in available $\mathrm{P}$ from that treatment. In the case of $\mathrm{N}$, the results contrast with the expected behavior since alum is thought to increase the total nitrogen content of the litter matrix by preventing ammonia losses.

\section{CONCLUSIONS}

Addition of alum at a $20 \%(\mathrm{w} / \mathrm{w})$ rate resulted in a significant reduction in the "soluble" $\left(\mathrm{CaCl}_{2}\right) \mathrm{P}$ fraction of the broiler litter matrix. As a result, the soils amended with broiler litter ( 6 and $20 \mathrm{t} / \mathrm{ha}$ ) containing alum at a $20 \%$ rate received $43 \%$ and $75 \%$ less soluble $\mathrm{P}$ than their untreated (no alum) counterparts. Additions of alum at the highest litter rate (i.e., 20 t/ha-20\% alum) achieved a $52 \%$ reduction in the concentration of TP in runoff in comparison to that of the no-alum treatment. However, the benefits of alum were more notable in the reduction of dissolved P (DP) losses. Average DP concentration losses for the $20 \mathrm{t} / \mathrm{ha}$ broiler litter rate (no alum) was $3.55 \mathrm{mg} / \mathrm{L}$, whereas the $10 \%$ and $20 \%$ alum treatments attained reductions of $58 \%$ and $70 \%$ of the DP concentrations in runoff, respectively. The observed DP concentration losses from the treatment containing $20 \%$ alum met the $1 \mathrm{mg} / \mathrm{L}$ threshold value in almost all instances at either litter rate. A rainfall event conducted under wet conditions (second event) caused a significant increase in TP and DP concentrations for all treatments, except for the treatment containing $20 \%$ alum at the higher broiler litter rate. DP concentration losses for this event were $85 \%$ lower at the $20 \%$ alum treatment than at the treatment containing no alum. Alum additions did not influence nitrate concentration losses at either litter rate. However, higher concentration losses of TKN were observed with additions 
of alum at the highest litter rate. Alum did not seem to exert a significant impact on the nutritional content of the Bermuda grass, although a slight decrease (non significant) in both $\mathrm{N}$ and $\mathrm{P}$ was observed at the $20 \%$ alum rate for the $20 \mathrm{t} / \mathrm{ha}$ broiler litter rate. It is concluded that alum represents a viable alternative for reducing phosphorus export concentrations from soils amended with broiler litter in Puerto Rico.

\section{LITERATURE CITED}

Cooperband, L. R. and L. Ward-Good, 2002. Biogenic phosphate minerals in litter: implications for phosphorus loss to surface waters. Env. Sci. and Technol. 36(23):50755082 .

DeLaune, P. B., P. A. Moore, D. K. Carman, A. N. Sharpley, B. E. Haggard and T. C. Daniel, 2004. Development of phosphorus index for pastures fertilized with broiler litter-factors affecting phosphorus runoff. J. Env. Qual. 33:2183-2191.

Martínez, G. A., R. Macchiavelli and M. A. Vázquez, 2010. Evaluation of best management practices to reduce nutrient contaminant losses in runoff from broiler litter amended soils. II. Grass cover. J.Agric. Univ. P.R. 94(1-2):61-77.

Martínez, G. A., M. A. Vázquez, J. L. Guzmán, R. Ramos-Santana and O. Santana, 2007. The Use of polyacrylamide as an erosion control strategy in a highly eroded soil of Puerto Rico. J.Agric. Univ. P.R. 91(3-4):87-100.

Martínez, G. A., D. Sotomayor and J. A. Castro, 2002. Application of the Caribbean P index to tropical soils receiving organic amendments. J. Agric. Univ. P.R. 86 (3-4):145154.

Moore, P. A., Jr. and D. R. Edwards, 2007. Long-term effects of broiler litter, alum-treated litter, and ammonium nitrate on phosphorus availability in soils. J. Env. Qual. 36:163-174.

Moore, P. A., Jr., T. C. Daniel and D. R. Edwards, 2000. Reducing phosphorus runoff and inhibiting ammonia loss from broiler litter with aluminum sulfate. J. Env. Qual. 29:37-49.

Ortega-Achury, S., G. A. Martínez and D. Sotomayor-Ramírez, 2007. Nutrient concentrations in runoff from different manure amended fields of the tropies under natural rainfall conditions. J. Agric. Univ. P.R. 91(3-4):101-116.

Parry, R., 1998. Agricultural phosphorus and water quality: A U.S. Environmental Protection Agency perspective. J. Environ. Qual. 27:258-261.

Puerto Rico Environmental Quality Board, 2008. Puerto Rico water quality inventory and list of impaired waters. 2008. 305(b)/303(d).

Ramírez-Ávila, J. J., 2005. Transporte de sedimentos y fósforo en escorrentía bajo simulación de lluvia. M.S. Thesis. University of Puerto Rico. Mayagüez Campus. http:// grad.uprm.edu/tesis/ramirezavila.pdf

Sato, S., D. Solomon, C. Hyland, Q. M. Ketterings and J. Lehmann, 2005. Phosphorus speciation in litter and litter-amended soils using XANES spectroscopy. Env. Sci. and Technol. 39(19):7485-7491.

Sharpley, A. N., 2000. Agriculture and phosphorus management: The Chesapeake Bay. Lewis Publishers.

Sims, J. T., 2000. Soil test P: Olsen P. In: G. M. Pierzinsky (Ed.). Methods of P analysis for soils, sediments, residuals, and waters. pp. 20-21, Bulletin no. 396.

Sims, J. T. and N. J. Luka-McCafferty, 2002. On-farm evaluation of aluminum sulfate (alum) as a broiler litter amendment: Effect on litter properties. J. Environ. Qual. 31:2066-2073. 
Smith, D. R., P. A. Moore Jr., D. M. Miles, B. E. Haggard and T. C. Daniel, 2004. Decreasing phosphorus runoff losses from land-applied broiler litter with dietary modifications and alum addition. J. Env. Qual. 33:2210-2216.

USDA, 2001. Confined animal production and litter nutrients. Agriculture Information Bulletin Number 771.

USDA-NRCS, 2001. National phosphorus project for simulated rainfall: Surface runoff studies. Protocol. Online.http://pswmru.arsup.psu.edu/phosphorus/nprp.htm

USEPA, 1983. Methods for chemical analyses of water and wastes. USPEA number. 600479020.http://yosemite.epa.gov/water/owrccatalog.nsf/ 065ca07e299b464685256ce50075c11a/f995d 73aff86600085256b0600724015!OpenDocument

Warren, J. G., S. B. Phillips, G. L. Mullins and L. W. Zelany, 2006. Impact of alum-treated broiler litter applications on fescue production and soil phosphorus fractions. Soil Sci. Soc. Am. J. 70:1957-1966. 
